\title{
Ecosystem service assessment of selected wetlands of Kolkata and the Indian Gangetic Delta: multi-beneficial systems under differentiated management stress
}

\author{
Mark Everard $(\mathbb{D} \cdot$ Rajiv Kangabam • Manoj Kumar Tiwari • Rob McInnes • \\ Ritesh Kumar • Gautam Hirak Talukdar • Harry Dixon • \\ Priya Joshi · Richard Allan - Dhaval Joshi - Lalu Das
}

Received: 7 February 2019/Accepted: 3 May 2019/Published online: 14 May 2019

(C) The Author(s) 2019

\begin{abstract}
A structured literature review using the search term 'ecosystem services' found few relevant studies relating to three contrasting wetlands in West Bengal: the unpopulated Sudhanyakhali Island in the Sundarbans National Park, the populated Gosaba Island separated from Sudhanyakhali Island by a narrow channel, and the East Kolkata Wetland (EKW). Subsequent structured review focused on the EKW using specific service-related terms located only 2 provisioning, 6 regulating, 1 cultural and 3
\end{abstract}

Electronic supplementary material The online version of this article (https://doi.org/10.1007/s11273019-09668-1) contains supplementary material, which is available to authorized users.

\section{Everard $(\bowtie)$}

University of the West of England (UWE), Coldharbour Lane, Frenchay Campus, Bristol BS16 1QY, UK

e-mail: mark.everard@uwe.ac.uk

\section{R. Kangabam}

Department of Agricultural Biotechnology, Assam Agricultural University, Jorhat, Assam 785013, India e-mail: rajiv.kangabam@gmail.com

M. K. Tiwari

School of Water Resources, Indian Institute of Technology Kharagpur, Kharagpur, WB 721302, India e-mail: mktiwari@swr.iitkgp.ac.in

\section{R. McInnes}

RM Wetlands and Environment Ltd, Littleworth, Oxfordshire SN7 8EQ, UK

e-mail:rob@rmwe.co.uk supporting services. Few services are currently recognized in the literature, with significant gaps in whole service categories. Significantly, there was no published evidence of a systemic overview of service production at these sites. Field observations and stakeholder dialogue informed assessment of ecosystem services using the Rapid Assessment of Wetland Ecosystem Services (RAWES) approach, adopted by the Ramsar Commission, on both islands and three discretely different areas of the EKW. The RAWES surveys found that 32 of 36 ecosystem services were produced from at least one assessed wetland site. Despite low sample size, statistically significant differences were observed in the range of services produced between the five wetland sites and the

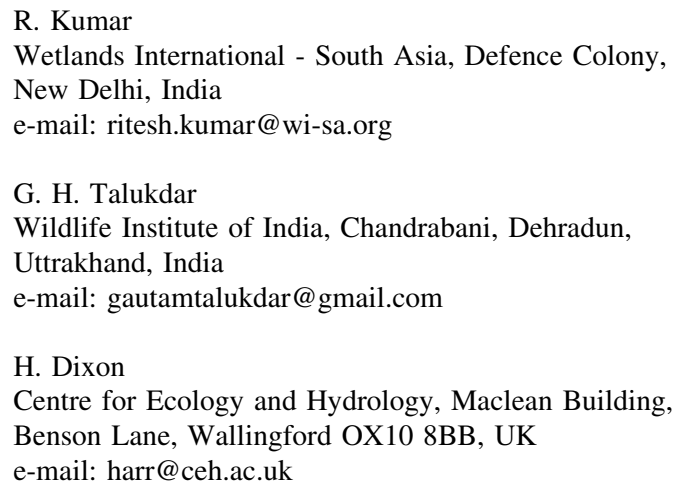


geographical range at which benefits accrued, explained by differing wetland characteristics and management regimes. Were decisions based solely on evidence provided by existing published knowledge, few ecosystem services would be considered and, potentially, whole ecosystem service categories might be overlooked. Importantly, there would also be no systemic account of service production and interdependencies. RAWES assessment serves as a practical, rapid and systemic approach, taking account of interdependent ecosystem services, supporting protection of the ecological character and achievement of wise use of wetlands. RAWES can also help redress perceptions that the values of periurban wetlands are currently under-represented.

Keywords Sundarbans - East Kolkata Wetland · RAWES · Ramsar · Wise use ·

Ecosystem services index

\section{Introduction}

Wetland systems provide a diversity of beneficial ecosystem services for society. Human uses inevitably affect natural character and service production -attributes germane to Wise Use guidance under the intergovernmental 1971 Ramsar Convention on wetlands of international importance (https://www.

\section{P. Joshi}

Indian Institute of Tropical Meteorology, Dr. Homi

Bhabha Road, Pashan, Pune 411008, India

e-mail: priya.joshi@tropmet.res.in

\section{R. Allan}

The James Hutton Institute, Invergowrie, Dundee DD2 5DA, UK

e-mail: richard.allan@hutton.ac.uk

D. Joshi

Advanced Center for Water Resources Development and Management (ACWADAM), Pune, India

e-mail: dhavalgy@gmail.com

\section{Das}

Department of Agricultural Meteorology and Physics, Bidhan Chandra Krishi Viswavidyalaya (BCKV),

Mohanpur, Nadia, West Bengal 741 252, India

e-mail: daslalu@yahoo.co.in ramsar.org/)—influencing the capacities of wetlands to sustain wildlife and support human wellbeing.

The Ganges and Brahmaputra river systems combine to form the Ganges-Brahmaputra Delta draining into the Bay of Bengal, comprising the world's largest delta at $105,000 \mathrm{~km}^{2}$ spanning Bangladesh and the Indian state of West Bengal. The delta region is highly biodiverse and agriculturally fertile, naturally comprising networks of distributary channels, lakes and floodplains. The seaward deltaic islands constitute the Sundarbans, the world's largest tract of contiguous mangrove forest (Raha et al. 2012) comprising many species. The Sundarbans support characteristic large fauna including Bengal Tiger (Panthera tigris tigris), Indian Python (Python molurus), Saltwater Crocodile (Crocodylus porosus), Ganges River Dolphin (Platanista gangetica gangetica), various marine dolphin species and an abundance of fishes and crustaceans for which the delta is an important recruitment area. India declared Sundarban National Park as the core area of Sundarban Tiger Reserve in 1973, designating it as a wildlife sanctuary in 1977, a UNESCO World Heritage Site in 1987, and a Ramsar site in 2019.

The Ganges-Brahmaputra delta is also one of the world's most densely populated regions, supporting 108 million people at a density of approximately 1280 people per $\mathrm{km}^{2}$ (Ericson et al. 2006) increasing by approximately 19 million people between 1991 and 2011 (Szabo et al. 2016). However, the delta is low-lying, its first distributary channel (the Hoogli river) at an altitude of $18-20 \mathrm{~m}$ asl at the Farraka Barrage (Szabo et al. 2016). Low topography confers benefits through wetland productivity and accessibility to sea-going cargo, the Indian city of Kolkata (formerly Calcutta) with a floating, rising pollution of some 4.4 million people comprising a major port. The Sundarbans is also home to some of the world's poorest people (Roy and Guha 2017). The Indian Sundarbans human population rose from 1.15 million in 1951 to 4.44 million in 2011 (Ghosh et al. 2015), $56 \%$ of which are landless and dependent on natural resources for agriculture, fishery and non-timber forest products (Singh et al. 2010; Ghosh and Boykoff 2018).

Development planning within the delta has focused on hard engineering approaches, characterized by construction of dykes and structures to regulate water flows upstream. The delta has thus 
been deprived of over $35 \%$ of riverine sediment inputs compared with historical rates (Gupta et al. 2012), placing the integrity of the delta in peril (Syvitski et al. 2009). Engineered solutions have induced a false sense of security amongst delta inhabitants, exposing the significant population buildup around the dykes to risks of embankment breaches. The role of mangroves in sediment accretion and securing coastline has been critical (Raha et al. 2012). The value of Sundarbans as natural ecological infrastructure has been highlighted, for example, by valuation of ecosystem degradation and biodiversity loss in the Indian Sundarbans at US\$ 0.14 billion annually (2009 prices), equivalent to $4.8 \%$ of the region's GDP (World Bank 2014).

The Sundarbans is also vulnerable to climate change through factors such as sea level rise at a high rate $(3.5 \mathrm{~mm}$ per year) compared to other oceans globally (Hazra et al. 2002; Raha et al. 2012), an accelerated rate of sea water warming $\left(0.5{ }^{\circ} \mathrm{C}\right.$ per decade over the Bay of Bengal compared to global rate of $0.06{ }^{\circ} \mathrm{C}$ per decade: Centre for Science and Environment 2012), variability in salinity trends with some regions increasing and others decreasing (Trivedi et al. 2016), eroding delta islands, increasing soil and water salinity, and decreasing crop viability (Mahadevia and Vikas 2012). Susceptibility to sea level rise and tsunami storms is exacerbated by degradation of mangrove buffer zones (Deb and Ferreira 2016). The Sundarbans coastline is in a net erosional state, the delta front undergoing net erosion of $\sim 170 \mathrm{~km}^{2}$ of coastal land between 1973 and 2010 (Rahman et al. 2011). Erratic monsoon rains and intense cyclones increase stresses, severe cyclonic Storm Aila killing many people in India in 2009, leaving hundreds homeless and causing massive damage to trees, roads and infrastructure (Times of India 2009). There is looming awareness of the risk of the Sundarbans entirely submerging unless urgent global action is undertaken to reduce greenhouse gas emissions (Mahadevia and Vikas 2012). Climate change is driving food and water insecurity and, consequently, poverty and outmigration from the Sundarbans (Sanchez-Triana et al. 2018). In the Bangladeshi region of the Sundarbans, potential decline in wetland ecosystem services such as provision of food and raw materials due to sea level rise are projected to drive losses of US\$ 0-1 million to US\$ 16.5-20 million under different scenarios
(Mehvar et al. 2019). It is consequently essential to understand the role of wetlands in the region beyond human uses. Ensuring wetland conservation and sustainability will be key to mitigate and address the challenges posed by climate change and allied events.

We review the ecosystem services provided by a small subset of wetlands in the outer Indian Sundarbans islands and different zones of the East Kolkata Wetlands (EKW) to the east of Kolkata city. The study includes what is known in the literature about ecosystem service production by these wetlands. Ecosystem service production at the selected study sites was then assessed using the Rapid Assessment of Wetland Ecosystem Services (RAWES) approach, adopted under Ramsar Resolution XII.17 (Ramsar Convention 2018) as a rapid and cost-effective method for the systematic assessment of ecosystem services provided by wetlands. Comparison of ecosystem services addressed in the literature with field assessments tests the value and utility of RAWES, and provides insights that may inform future wetland management and wise use challenges.

\section{Methods}

Three methods were undertaken to determine ecosystem service production at study wetland sites: structured literature review of published knowledge about ecosystem service production; and field-based rapid assessment of ecosystem services.

The study sites

Two principal wetland areas of differing character were selected for study of their ecosystem services: an unpopulated outer Sundarbans island within the World Heritage Site and Tiger Reserve (Sudhanyakhali Island); a populated outer Sundarbans island adjacent to the protected island (Gosaba Island); and the East Kolkata Wetland, in which three differing zones were selected for further study (Fig. 1).

Study regions were addressed opportunistically, adjunct to a related study, rather than selected specifically for the purpose of the rapid field assessment of ecosystem services. They nonetheless represent a spectrum from protected and populated 


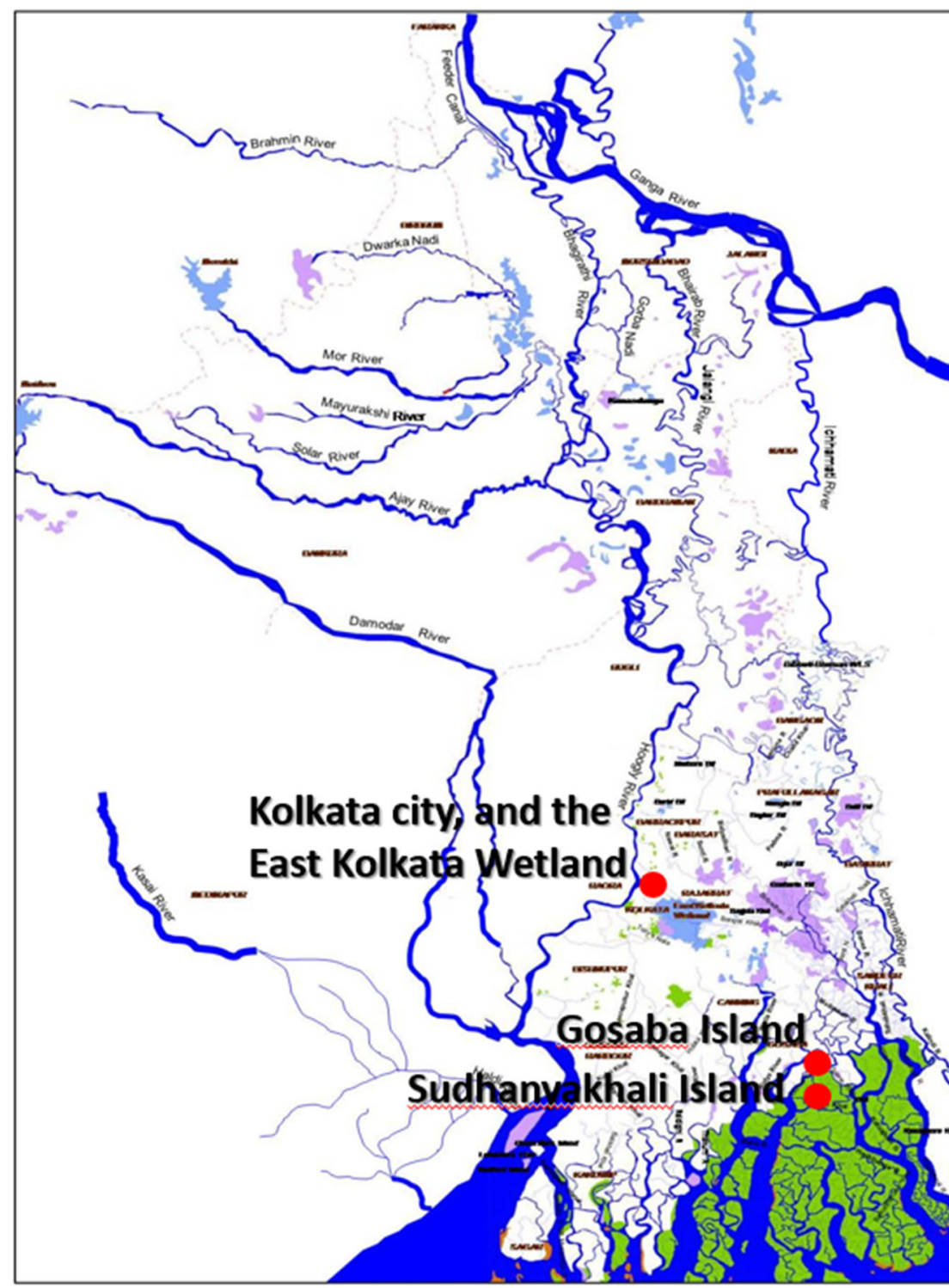

Assessed wetland sites

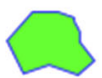

Protected Sundabans islands

认

Channel or sea

$20 \mathrm{~km}$

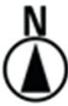

Fig. 1 Wetland and island areas selected for this study showing the connection of the EKW with the Sundarbans and wider GangesBrahmaputra delta (base image Wetlands International South Asia)

outer islands to heavily utilised peri-urban wetlands. Initial conclusions from ecosystem service assessment of these diverse sites reflect some of the heterogeneity of wetlands and their services in West Bengal.

\section{Sudhanyakhali Island}

Sudhanyakhali Island $\left(22.1058^{\circ} \mathrm{N}, 88.7841^{\circ} \mathrm{E}\right)$ is a major island protected from human encroachment and use (except for tightly managed ecotourism resorts) within India's Sundarban National Park, Tiger Reserve and World Heritage Site. About 60\% of the Indian Sundarbans (48 unpopulated islands) is protected and unpopulated, with the remaining 54 islands human-inhabited.

A multi-disciplinary team traversed Sudhanyakhali Island by boat on 11th December 2018, further synthesising learning on 12th December. Though not permitted access, which would have been difficult due to thick mud, extensive mangrove forest offering little visibility and also wild Tigers and Saltwater 
Crocodiles, the boat trip close to the shoreline sufficed for observations albeit limiting visibility of the island interior.

\section{Gosaba Island}

Gosaba Island $\left(22.145^{\circ} \mathrm{N}, 88.807^{\circ} \mathrm{E}\right)$ is a principal populated island in the outer delta. Administratively, Gosaba Island lies in the Canning Community Development Block within South 24 Parganas District, West Bengal. A Panchayat (local community governance system) covers all 14 villages on the island, encompassing a total population of 246,598 comprising 125,910 males and 120,688 females, wholly classified as rural (2011 Census of India). Predatory animals and periodic famine were historically problematic, low topography also making Gosaba vulnerable to sea level rise and cyclones. Storm Aila inundated Gosaba Island in 2009, with resulting distress migrations (some permanent) for alternative livelihoods to adjacent cities. Seawater permeated the soil, preventing farming for 2 years as efforts were taken (led by island NGO Tagore Society for Rural Development) to flush salt from the soil using monsoon run-off and groundwater.

A multi-disciplinary team of scientists, NGOs and outreach organisations visited Gosaba Island on 9th11th December 2018, including a boat tour around Gosaba and adjacent populated islands to observe features of interest, with further synthesis of learning on 12th December. The team interacted with local people, community and government representatives, and invited experts working on the ground (see "Appendix"). Team objectives were to hear perceptions of problems from local people, seek solutions and identify barriers, and inform research needs.

\section{The East Kolkata Wetland (EKW)}

The East Kolkata Wetland (EKW) $\left(22.5528^{\circ} \mathrm{N}\right.$, $88.4501^{\circ} \mathrm{E}$ ), formerly the East Calcutta Wetland, comprises a complex of modified wetlands spanning $215 \mathrm{~km}^{2}(21,500 \mathrm{ha})$ to the east of the city of Kolkata in West Bengal. The EKW, initially a saltmarsh, was used as a site to discharge city's sewage, but subsequently transformed over many years by local people into an extensive maze of sewage-fed fish farms and paddy fields (Kundu et al. 2008). Wastewater (no published water quality analyses were available) is diverted into fish ponds and tilled areas under community ownership and management from channels carrying the bulk of untreated drainage from the Kolkata megacity region with a population of 14.1 million (Ghosh and Das 2019). Channel height is controlled manually by sluice operation. The EKW produces much of the fish, vegetable and flower needs of Kolkata city, serving as primary treatment of raw sewage and significantly shaping the characteristic EKW landscape (Ghosh and Furedy 1984; Ghosh and Sen 1987) underpinning the livelihoods of $74 \%$ of the working population of adjoining areas (Kundu and Chakraborty 2017; Ghosh et al. 2018). The EKW acts as important habitat for various wildlife including birds (Bhattacharya et al. 2012). Traditional pisciculture and cultivation techniques and knowledge form the basis of ecological security of the region (Kundu and Chakraborty 2017), a wise use providing multiple benefits including food production, resource recovery, flood reduction, habitat and biodiversity restoration, and opportunities for employment. The EKW was designated as a "wetland of international importance" under the Ramsar Convention in August 2002, noting it as "Worldrenowned as a model of a multiple use wetland, the site's resource recovery systems, developed by local people through the ages, have saved the city of Kolkata from the costs of constructing and maintaining waste water treatment plants" also "...utilizing the treated water for pisciculture and agriculture" providing "about 150 tons of fresh vegetables daily" and "some 10,500 tons of table fish per year" (Ramsar Commission Secretariat 2002). Under the East Kolkata Wetlands (Conservation and Management) Act 2006, formal protection was afforded these wetlands and the East Kolkata Wetlands Management Authority (EKWMA), chaired by the Chief Secretary of the Government of West Bengal, was established for conservation and management of the EKW.

EKW wetland area has reduced comprehensively over 40 years through urban expansion of Kolkata metropolitan city, much of it illegal, potentially compromising sustainable development of the city/ region (Parihar et al. 2013). Mondal et al. (2017) projected that only $39 \%$ of wetland area will remain by 2025 under current urban growth trends, underlining the vital importance of institutional coordination, financial support and land use regulations. Bhattacharya et al. (2012) additionally list 


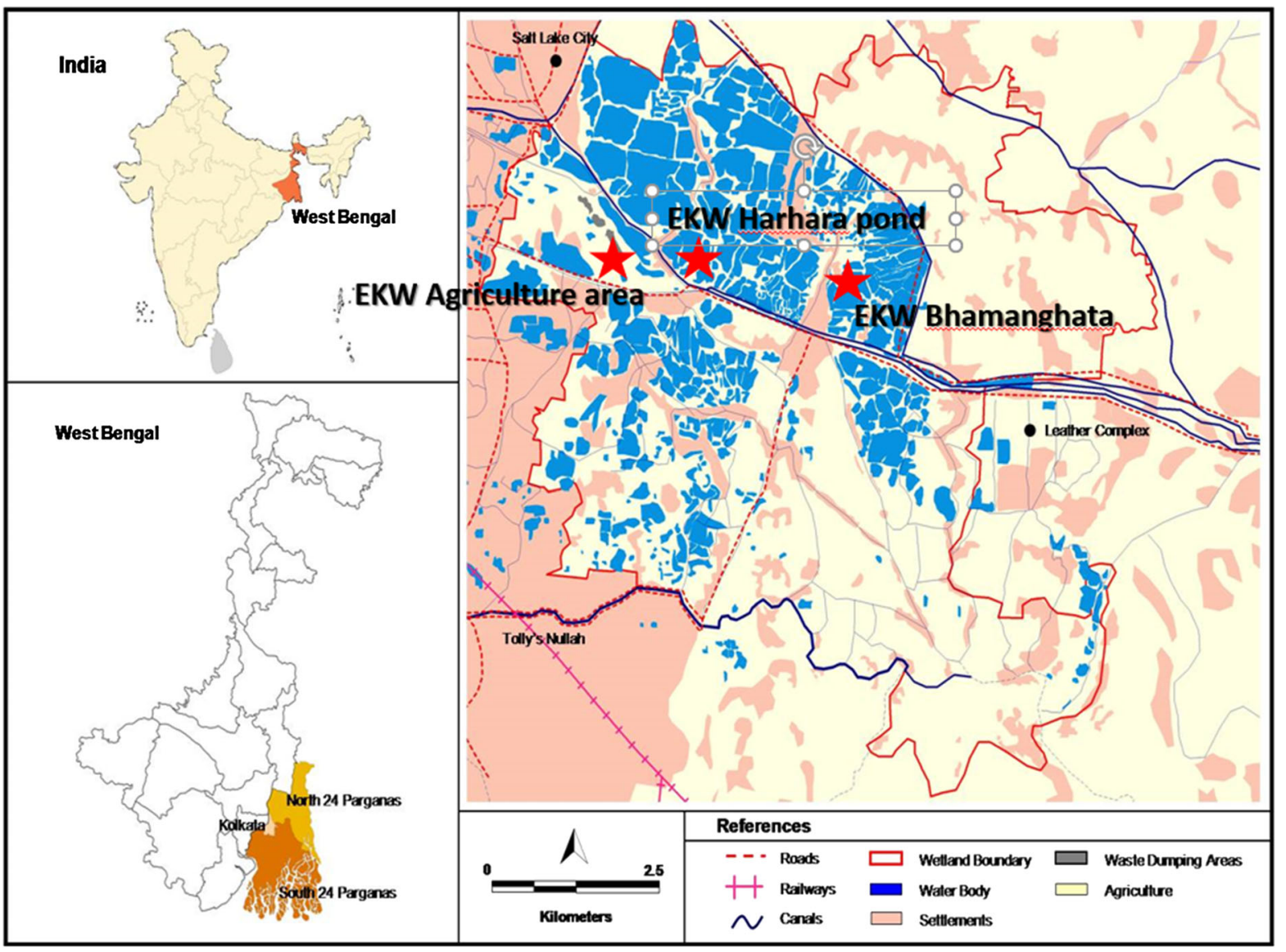

Fig. 2 Wetland areas selected for different predominant types of use in the EKW (base image Wetlands International South Asia)

industrial pollution, siltation, weed infestation and changed land use patterns as continuously damaging the ecological health of the EKW, emphasising the need for sustainable policies. Currently, there is no central zonation or strategy, though the EKWMA has reportedly been intending to publish a strategy and zonation plan for some years. A city decision to extend the Salt Lake City area by converting wetland area was successfully challenged by community groups under India's Public Interest Litigation (PIL) system in a landmark judgement of Calcutta High Court, saving the wetlands.

A multi-disciplinary team of scientists, NGOs and outreach organisations, some overlapping with the team visiting the Sundarbans, visited the EKW on 14th December 2018, interacting with various experts, managers and local people, with a further day of interviews with local stakeholders and synthesis of learning in Kolkata on 15th December. Three areas of the EKW (Fig. 2) were selected for detailed observations and interactions with local people, community representatives and invited experts (see "Appendix"):

- Harhara pond, a relatively small (4.867 ha using https://acme.com/planimeter/) fish pond under community control and benefit-sharing;

- Bamanghata, a large area (spanning 149.8 ha using https://acme.com/planimeter/) of substantially sized and recently (April-May 2018) enlarged fish ponds comprising four main cells; and

- Agriculture area, an extensive strip between wastewater channels beside the Basanti Highway, producing vegetables, fruit and flowers.

Structured literature review for wetland ecosystem services

A literature review was undertaken linking the term 'ecosystem services' respectively with 
'sudhanyakhali' and 'gosaba'. It is recognised that many services (food production, storm regulation, etc.) have been studied, but the purpose of this search was to look at those explicitly recognised as ecosystem services.

An additional structured literature review was undertaken specifically focused on the EKW. The search terms 'east Kolkata wetland' or 'east calcutta wetland' were linked with a range of terms germane to ecosystem services ('provisioning', 'regulatory' or 'regulating', 'cultural' supporting', 'fish' or 'fisheries', 'food', 'treatment', 'nutrient' or 'nutrients', 'purification', 'carbon', 'bird OR birds', 'nutrients OR nutrient', 'habitat').

The syntax of searches, dates of searches, databases assessed and search outcomes are submitted as Supplementary Material A.

RAWES assessment of wetland ecosystem services

An assessment of the ecosystem services of study wetlands was undertaken using the Rapid Assessment of Wetland Ecosystem Services (RAWES) approach (Ramsar Convention 2018; RRC-EA in press). RAWES was developed to support ecosystem service assessment of wetlands recognizing practical time and resource limitations faced by operational staff, providing a simple, user-friendly, cost-effective approach supporting systemic assessment of the full range of wetland ecosystem services (McInnes and Everard 2017). A systemic approach is important for expressing the condition of a wetland in a manner that informs ecosystem management (Stein et al.
2009). Genuinely rapid assessment is a key operational need identified by Fennessy et al. (2007) and Kotze et al. (2012), a guiding principle of RAWES being that no more than two appropriately trained people should spend no more than half a day in the field and another half-day of preparation and analysis. RAWES addresses the four ecosystem service categories (provisioning, regulatory, cultural and supporting, summarised in Table 1) defined by the Millennium Ecosystem Assessment (2005). Despite their redefinition as functions in some subsequent reclassifications (for example TEEB 2010; Braat and de Groot 2012) to avoid 'double-counting' benefits, supporting services are explicitly retained by RAWES recognising the necessity of integrating their vital underpinning roles into decision-making contexts to avert undermining the functioning and resilience of ecosystems, including their capacities to generate other services. RAWES can be used across a range of scales from whole-wetland to localised zones of large and complex wetlands, a facet exploited in this study.

Expert assessors interacted with numerous local stakeholders, community groups, government officials, NGOs and other interested parties (see "Appendix"). Consent to use anonymised feedback from interviewees was sought prior to interviews and meetings.

Semi-quantitative importance of each service was scored on a scale from 'significantly positive' (++) through 'neutral' $(0)$ to 'significantly negative' $(-)$ or 'unknown' (?) as outlined in Table 2. Data captured in hand-written RAWES field assessment sheets were transposed into spreadsheet format, with some

Table 1 Millennium Ecosystem Assessment (2005) ecosystem service categories

\begin{tabular}{|c|c|}
\hline $\begin{array}{l}\text { Millennium Ecosystem Assessment (2005) } \\
\text { ecosystem service category }\end{array}$ & Summary description \\
\hline Provisioning & $\begin{array}{l}\text { Physical and other resources extracted from ecosystems to support a diversity of } \\
\text { human needs, such as food, fibre and natural medicines }\end{array}$ \\
\hline Regulating & $\begin{array}{l}\text { Regulatory processes within ecosystems maintaining balance, such as pollination, } \\
\text { water purification and climate moderation }\end{array}$ \\
\hline Cultural & $\begin{array}{l}\text { Aspects of ecosystems providing non-material benefits enriching society, such as } \\
\text { those supporting tourism, recreation and spiritual interests }\end{array}$ \\
\hline Supporting & $\begin{array}{l}\text { Processes within ecosystems that maintain overall functioning and resilience, such as } \\
\text { soil formation, photosynthetic production of oxygen and habitat for wildlife }\end{array}$ \\
\hline
\end{tabular}

Ecosystem services are defined by the Millennium Ecosystem Assessment (2005) as "...the benefits people obtain from ecosystems" 
Table 2 Transposition of RAWES 'importance of service' scores into numeric values for analysis and representation

\begin{tabular}{lllllll}
\hline Assigned importance & Significantly positive & Positive & Neutral & Negative & Significantly negative & Unknown \\
\hline Importance score & ++ & + & 0 & - & - & $?$ \\
Numerical value & 1.0 & 0.5 & 0.0 & -0.5 & -1.0 & Remove from analysis \\
\hline
\end{tabular}

modification in dialogue amongst assessors and other experts where more information became available. (Spreadsheets containing RAWES data are submitted as Supplementary Material B.) To express and compare production of the four ecosystem service categories at the five RAWES-assessed sites, assigned importance scores were numerically transformed as outlined in Table 2. Groups of ecosystem services (all 36 assessed services or within Millennium Assessment categories) were summed and divided by the number of services in that category (up to provisioning $n=9$, regulating $n=14$, cultural $n$ $=7$, supporting $\mathrm{n}=6$ but reduced where services were not relevant) to derive a single comparable ecosystem services index (ESI) (based on similar index methods by Butchart et al. (2010), Davidson et al. (in press) and McInnes et al. (in press). The ESI is calculated using Eq. 1. The potential ESI range is from +1 to -1 when calculated for each of the four ecosystem service categories, though compound values for all services can exceed these limits where benefits are realised at multiple geographical scales.

$\mathrm{ESI}=\frac{\sum\left(n_{+1.0}+n_{+0.5}\right)+\sum\left(n_{-1.0}+n_{-0.5}\right)}{\sum n_{\mathrm{TOTAL}}}$

\section{Results}

The results of field observations, literature review and RAWES field assessments are addressed for each of the five assessed wetland sites.

Literature-based overview of wetland sites

Literature references arising from the structured review linked to the term 'ecosystem services', also including an additional paper (Uddin 2011) located by a more general search, are addressed in Table 3 . The topics returned from the structured search using wider service-related terms linked to the EKW are summarised in Table 4.

Observations feeding into RAWES assessment and analyses of data

\section{Observations at Sudhanyakhali Island}

Extensive artisanal fishing boats operating in channels between islands make use of provisioning services resulting from the contributions to fishery recruitment. Communities on Gosaba Island reported illegal forays into the unpopulated islands of the Sundarbans to collect wild honey. Regulating services were evident through the dynamic geomorphology around uninhabited islands, extensive mud flat areas repopulating with mangrove seedlings and, in other places, retreating mangroves with air-breathing roots exposed stabilizing banks against erosive forces. These indicate hydrological, hazard regulation, carbon sequestration and nutrient cycling processes with far-reaching benefits beyond the islands. Carefully managed resorts on the island and peripheral boat tours provide significant revenue from ecotourism. Many more taxa and numbers of birds (albeit not quantified) were observed compared to adjacent inhabited islands, an indicator of supporting services. The extensive and dense mangrove forests intersected with tidal slews characterized areas visible by boat highlighting floral diversity, though impeding observation of island hinterland.

\section{Observations at Gosaba}

Gosaba Island is divided into multiple, family-owned plots with ponds of varying sizes dug into the clay adjacent to households to harvest and store monsoon water for multiple provisioning needs (drinking, washing, irrigation and fish production for subsistence use), agriculture constituting the overwhelming 


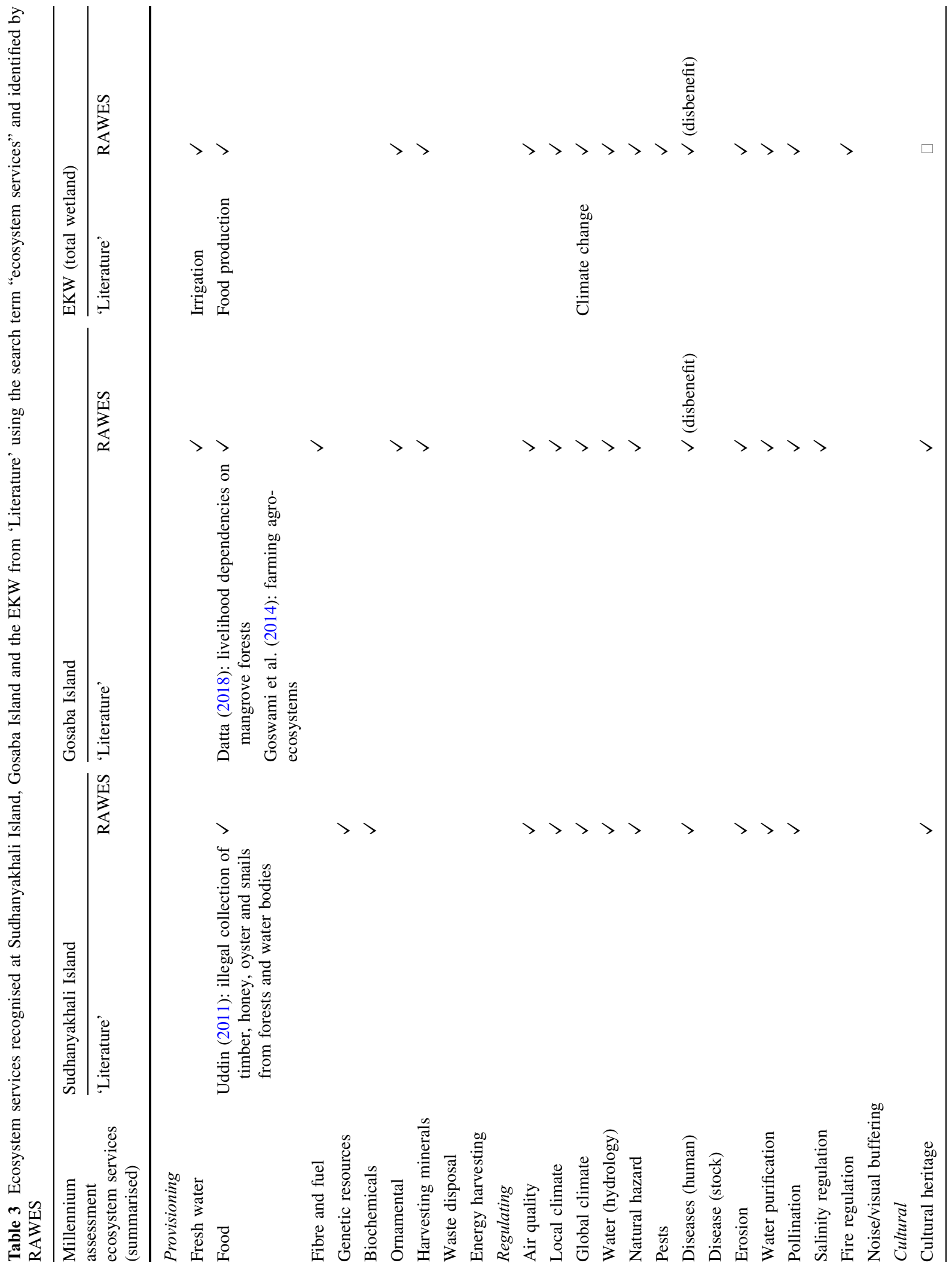




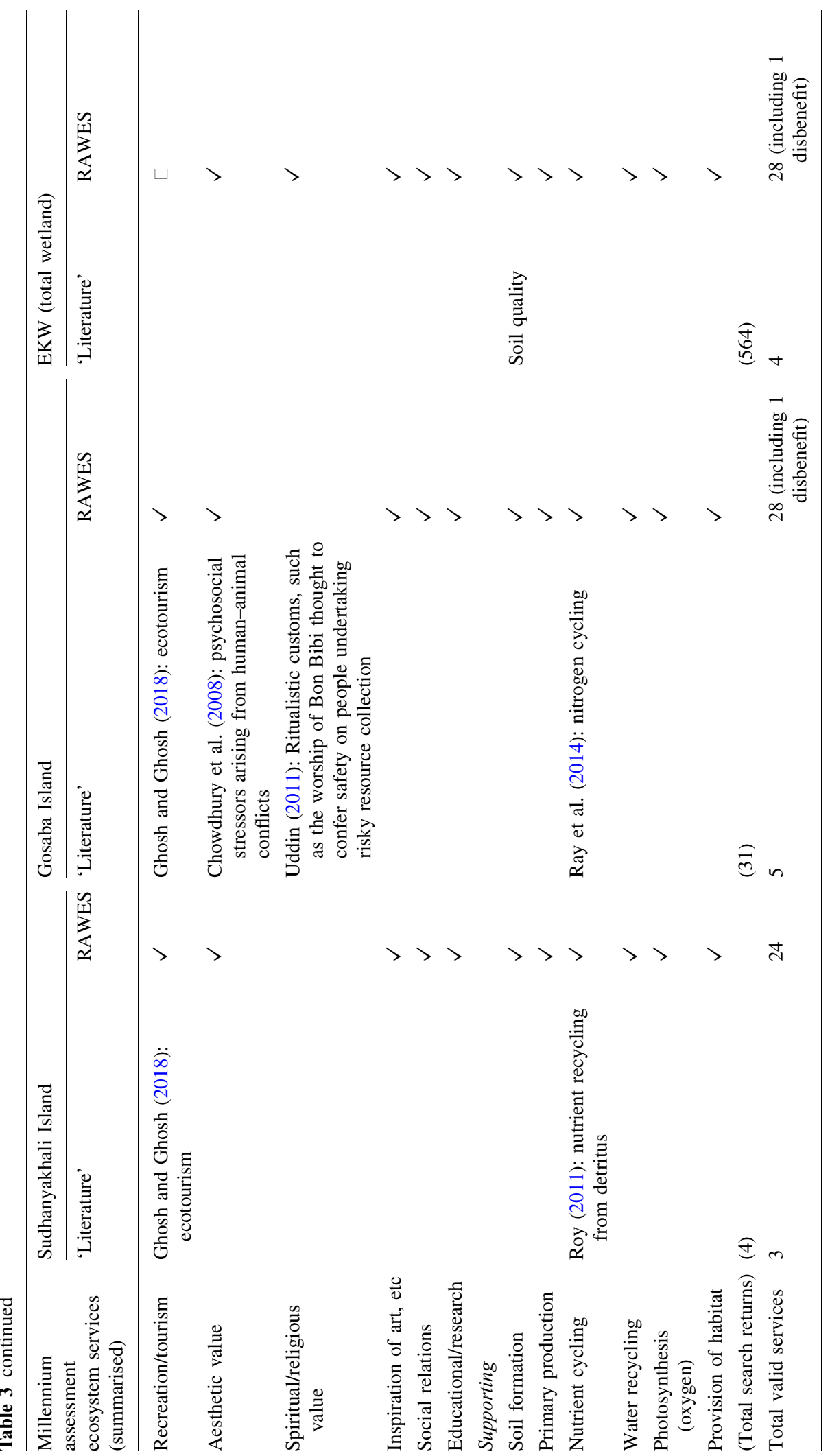




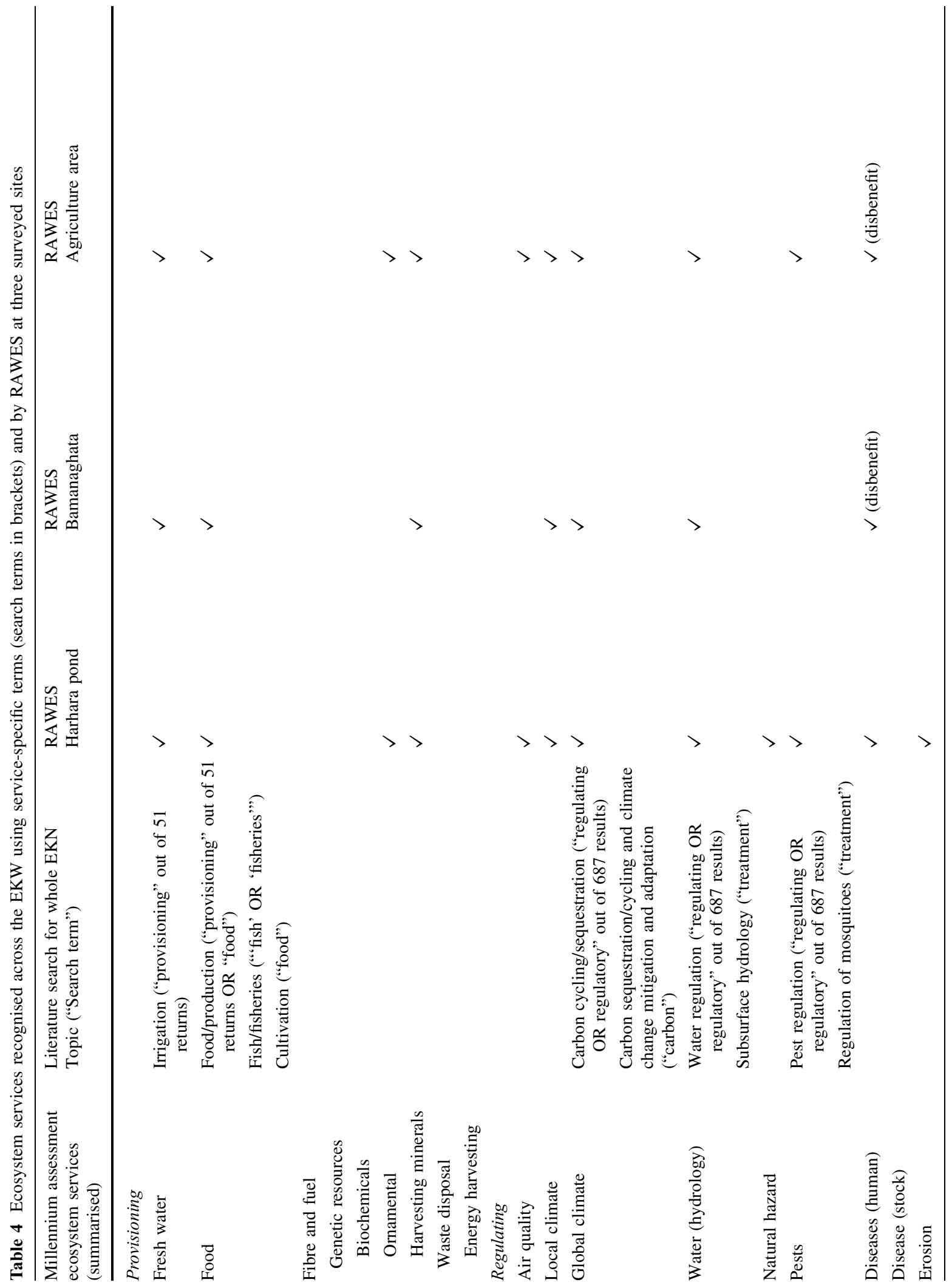




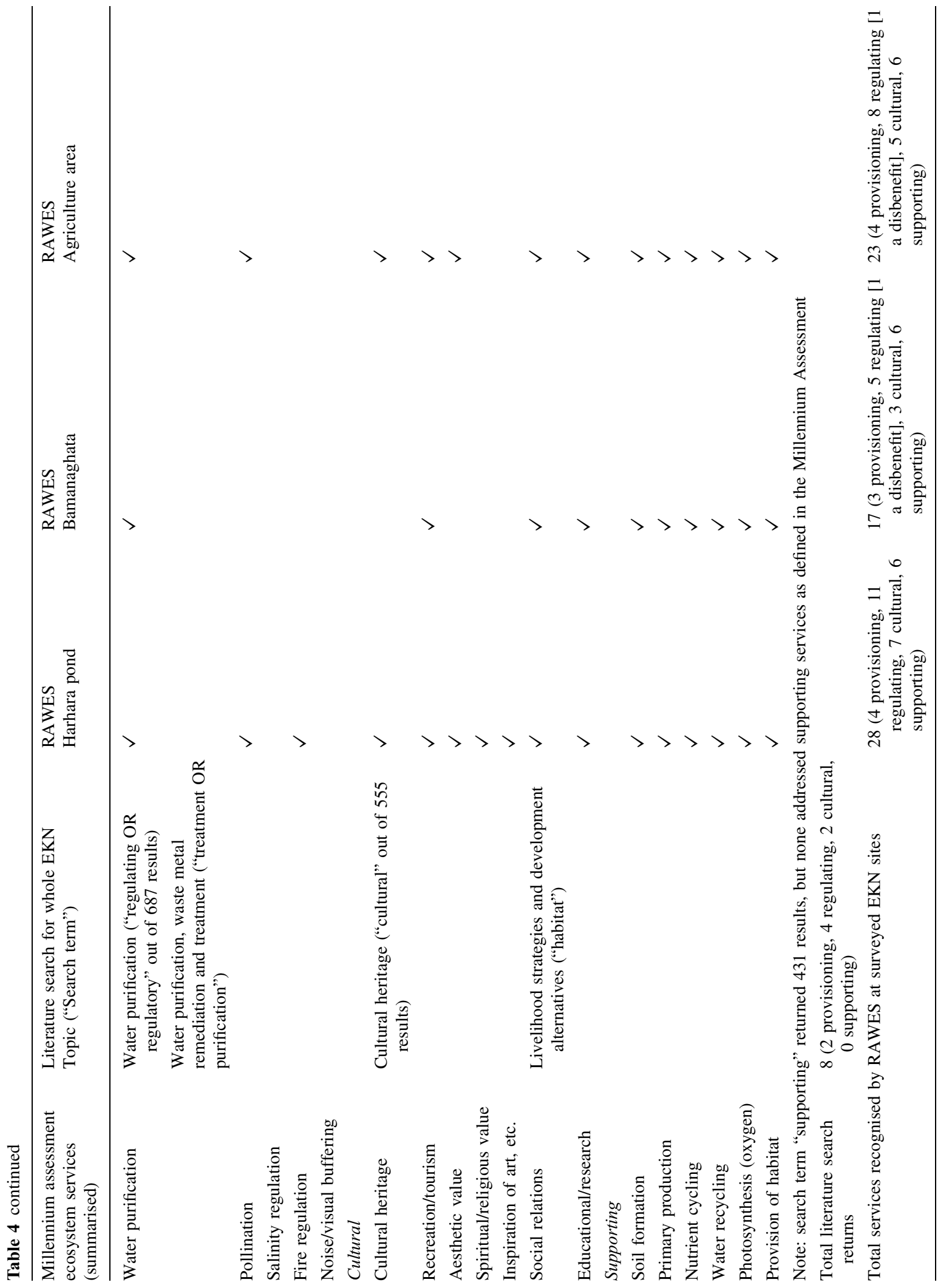


land use. The khariff (wet, post-monsoon, JulyOctober) crop substantially comprises rice; the rabi/ boro (second, winter/drier season) crop traditionally also comprised rice though agriculture largely stops when pond water is depleted in the pre-monsoon (March-May) season at which time many people migrate out to cities seeking employment. Government is promoting rabi/boro cropping of pulses and oilseed, but water insufficiency remains a greater problem on Gosaba compared to other populated islands with more reliable groundwater availability. Water-efficient techniques such as micro-irrigation are being promoted but are infrequently implemented, reportedly due to costs and lack of outreach to farmers. There is demand for salt-tolerant crops as salinity problems persist, though lower yields relative to mainstream strains is proving counter-productive. Livestock is sparse due to water scarcity but also as the island recovers slowly from Storm Aila, with only inorganic fertilisers (urea and ammonium phosphate) used due to the lack of livestock dung. Much of the region's shallow aquifer systems are saline, necessitating drinking and domestic water schemes dependent on groundwater tapped from aquifers at depths up to 2000 feet $(\sim 600 \mathrm{~m})$. Regulation of hydrology is artificially enhanced through water harvesting ponds, though local people are calling for government aid to deepen ponds shallowed due to infilling as a bulkhead against water insecurity. Climate change was cited as a threat with perceived erratic, delayed and declining rainfall patterns, though Choudhury et al. (2019) report premonsoon rainfall increases during 1979-2015 over the Bay of Bengal. The aftermath of Storm Aila generates lingering concern about risks from tsunamis, cyclones and thunderstorms. Pervasive 'hard' (concrete and packed clay) coastal banks erected around islands clearly constrain mangrove succession in areas appropriated as private landholding holdings, dynamic erosion and deposition patterns observed around uninhabited islands undercutting 'hard' defences at Gosaba and other populated islands with reduced storm and surge buffering also heightening risk further up the delta. Culturally, some small forest areas and ponds have spiritual uses, generally with associated temples. Limited production of handicrafts is undertaken, mainly by women. Cultural pressures on the Island include population growth resulting in subdivision of landholdings, which compromise water storage and farmed areas around households, and poor access to markets leaving households vulnerable to mediators offering low prices. Local people reported farmer suicides as a pernicious problem due to insoluble debt. Supporting services suffer from the observed 'squeeze' of intertidal habitats between channels and hard coastal defences, compromising habitat, soil formation, nutrient cycling and productivity.

\section{Observations at EKW Harhara pond}

Harhara pond is owned by a small community sharing its management, harvesting and profits with a focus on the provisioning service of fish production from wastewater, harvested and by substantial majority sold at the wholesale fish market at Banthala for onward distribution and retailing across Kolkata. The Harhara community also irrigate kitchen gardens with untreated wastewater supporting subsistence needs. Government-supplied tube wells provide water for domestic use, though local people bathe and wash utensils in the fish ponds. The EKW's regulating service of water purification averts substantial costs of a technical water treatment plant, maintenance costs for which are estimated as Indian ₹400 Crore (₹4 billion approximating \$US58 million) annually (Ghosh and Das 2019). Local people report being happy to use untreated water for intensive aquaculture and agriculture, citing savings on fish food, city authorities testing for some metals though potential pollutant accumulation features in the literature (see Supplementary Material C). The EKW is also recognised as contributing significantly to flood regulation for the city, sometimes referred to as "the kidneys of Kolkata city". Ghosh et al. (2018) lists groundwater recharge as a benefit of the EKW, though Kolkata is located on a bed of 30-40 m of clay and the subsurface geology of the EKW and surrounding area is blanketed by Quaternary fluviatile sediments which effectively avert pollutant infiltration to groundwater (Sahu and Sikdar 2008). Ponds such as Harhara are culturally important as a centrepiece for community management. No religious ceremonies are carried out on ponds or channels, though flags were inserted into some ponds as a blessing for a good crop. Limited ecotourism is also encouraged on working EKW wetlands. In terms of supporting services, soil formation at Harhara Pond results when the prolific 
growth of Water Hyacinth (Eichhornia crassipes) collected to keep the pond's centre clear is piled onto the banks. Clay is harvested from the pond bed, rolled into balls to catapult as a deterrent against avian predators. Other than marauding and unwelcome Little Cormorants (Microcarbo niger), no other water birds were observed on Harhara pond.

\section{Observations at EKW Bamanghata}

Dominant management of the large Bamanghata pond complex is for provisioning services: production of multiple fish species coordinated by the Chorchoria Fisheries Corporation Limited (CFCS) under similar communal arrangements to Harhara Pond, though shared by a larger community. Clay is also harvested from the pond bed, no longer used for brick-making but used instead for rebuilding pond banks. The large ponds provide regulating services in the form of water purification as pisciculture acts as primary treatment of wastewater draining from Kolkata, also contributing to flood buffering. Supporting services included observed (unidentified) duck species and Indian Pond Heron (Ardeola grayii) in small numbers loafing or flying over the open water of the large ponds, though reputedly many birds visit the ponds during migratory periods.

\section{Observations at EKW agriculture area}

The extensive strip agriculture of the EKW between wastewater channels adjacent to the Basanti Highway is extensively tilled for provisioning services: many types of vegetables (cabbage, tomato, lettuce, aubergine, squashes), fruit and plantain trees, and a variety of flowers support much of the demands of the adjacent city. Reported regulating services include flood buffering and primary treatment for wastewater, and the presence of butterflies, dragonflies and other flying insects indicates pollination services. The landscape is substantially human-modified, providing cultural services supporting the livelihoods of large numbers of local people. Vegetated areas between tilled plots demonstrated floral diversity and supported a variety of visible flying insects.

RAWES data analyses

Of the 36 ecosystem services assessed using RAWES, 32 were provided by at least one study site. (The four contextually irrelevant services were: waste disposal; energy harvesting from flows of air or water; regulation of disease in livestock; and visual or noise buffering.) When a service was recorded, it was predominantly a significantly positive or positive benefit. The disbenefit, where negative outcomes exceed benefits, was the regulation of human diseases recorded at Gosaba Island, EKW Bamanghata and EKW Agriculture area.

\section{Distinctions in service production between assessed wetland sites}

Calculating deviation from the mean of ecosystem service production using ESI values, broken down by service category in Fig. 3, reveals differences among the five sites. This differentiates particular services that any one site provides more or less than other sites.

Gosaba Island demonstrates a substantial salinity regulation service in comparison to the other sites. All the sites produce similar levels of supporting services with broadly similar positive deviation, though Sudhanyakhali Island demonstrates substantially higher provision of habitat (to be expected in a Protected site) and EKW Bamanghata provides less water recycling and nutrient cycling than the other sites.

Figure 4 illustrates combined ESI scores for all ecosystem services at each of the five sites, as well as a breakdown of ESI for each service category (provisioning, regulating, cultural, supporting). Combined ESIs by wetland site reveal that the large intensive ponds at EKW Bamanghata, though efficient in producing fish, score lowest in overall service production $(\mathrm{ESI}=0.25)$ whereas the protected Sudhanyakhali Island has the highest overall service production $(\mathrm{ESI}=0.58)$. Similar patterns are observed among the ESI scores for the five sites, with cultural and supporting services having a higher score than provisioning and regulating services. A KruskalWallis Test was conducted to examine the differences among the five study sites according to the different categories of ecosystem services. Significant differences $(k=11.003, p=0.027, \alpha=0.05)$ were found among the five study sites with EKW Bamanghata (mean score $=0.247$ ) and Sudhanyakhali Island (mean score $=0.559$ ) being significantly different than the other three sites. 
(a) Provisioning

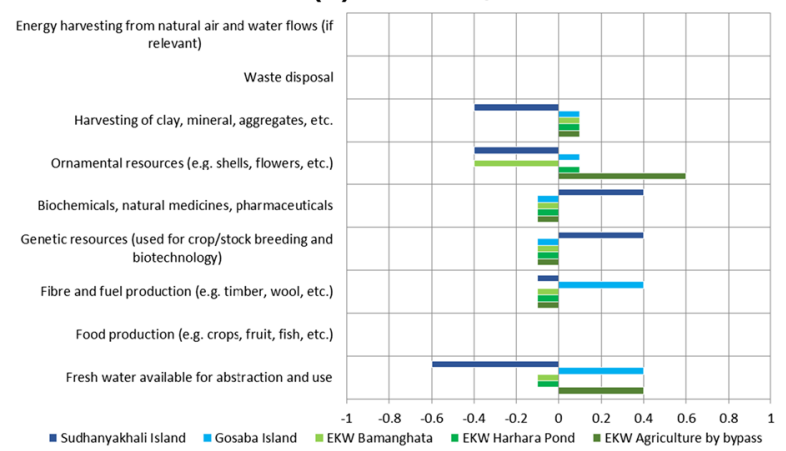

(c) Cultural

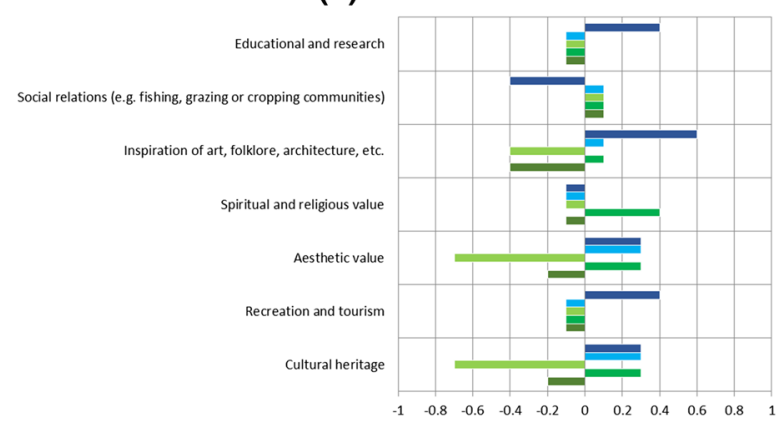

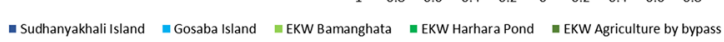

\section{(b) Regulating}

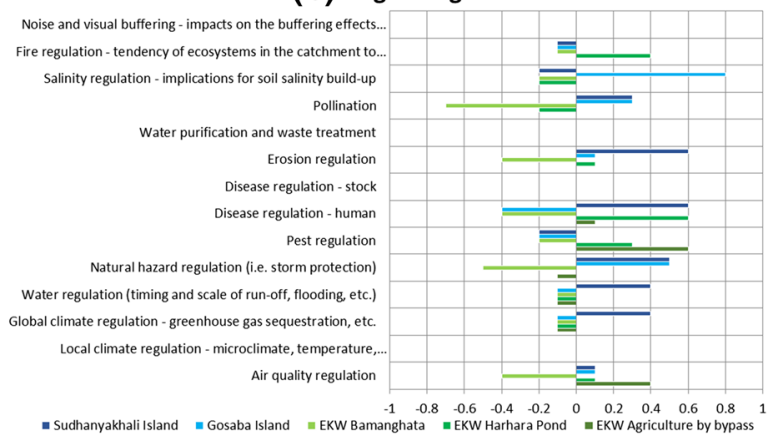

(d) Supporting

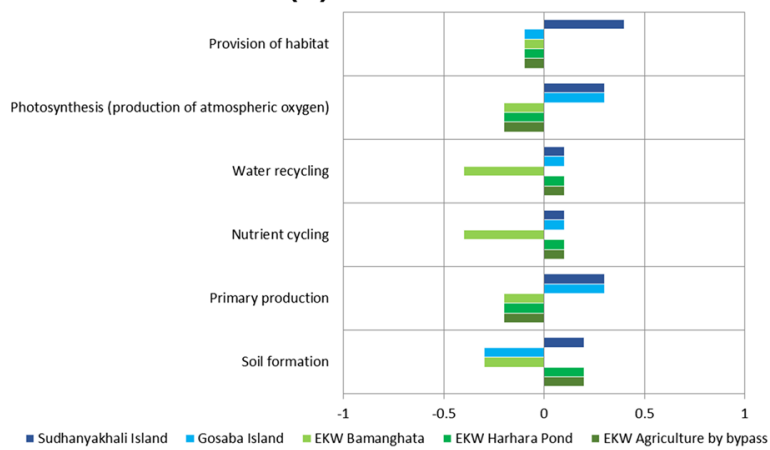

Fig. 3 Deviation from the mean (for all five sites) at each wetland site, broken down by service category, relative to production totalled across all sites: a provisioning, $\mathbf{b}$ regulating, $\mathbf{c}$ cultural and $\mathbf{d}$ supporting services

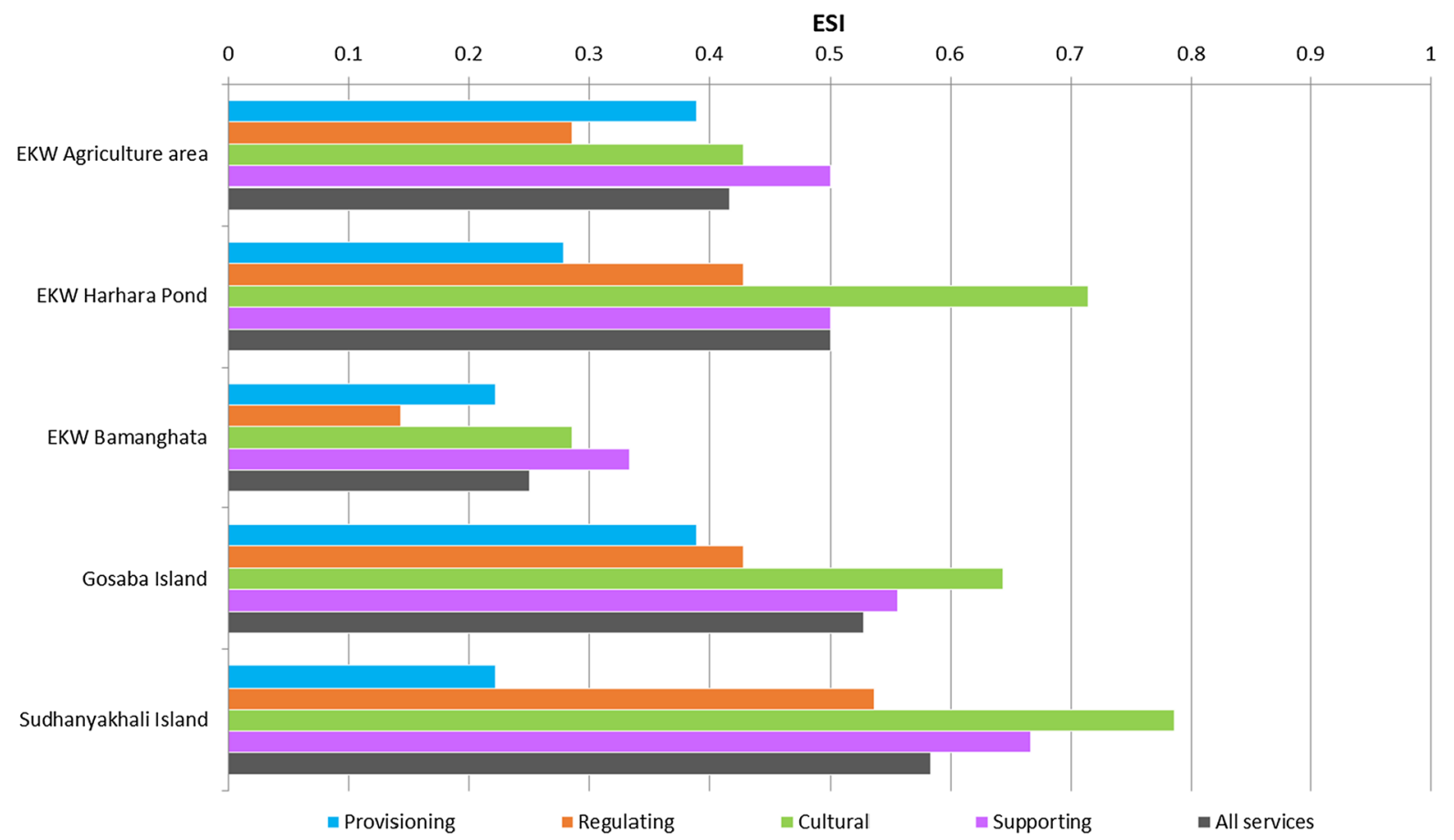

Fig. 4 ESI scores for all ecosystem services, and breakdown by ecosystem service category, at each of the study sites 
Differing geographical scales of service provision

RAWES assessments include recordings of differing geographical scales over which benefits from ecosystem services are realised. For this assessment exercise, four scales were considered: local (proximal to the wetland); adjacent catchment/city; national; and global. Geographical scale at which benefits accrue to people from each assessed wetland was standardized using ESI (Fig. 5). A Kruskal-Wallis Test was conducted to examine the differences among the five study sites according to the different scale at which the benefits from the ecosystem services accrue. No significant differences $(\mathrm{k}=$ 8.202, $p=0.084, \alpha=0.05$ ) were found among the scale at which benefits are delivered by the five study sites.

In all cases, local service provision was most prevalent; with adjacent catchment/city scale benefits second. Harhara Pond and Gosaba Island delivered the greatest ecosystem service benefits to the local community (ESI=0.694 for both sites). Sudhanyakhali Island produced greater national (ESI= $0.22)$ and global $(E S I=0.25)$ benefits, but a lower local level of benefit than other assessed wetland sites, both observations consistent with is Protected status. By contrast, the EKW Agriculture area site produced the lowest national and global benefits (ESI $=0.0$ and 0.06 respectively). The relatively lower level of ecosystem service provision recorded at the
EKW Bamanghata site (Fig. 4) was also manifest in the relatively lower degree to which benefits accrued across the four geographic scales (Fig. 5).

\section{Discussion}

Characteristics and management regimes at the five wetland sites differ markedly. Explicit recognition in the literature of ecosystem services generated by each site was low, though observed features and reported uses explain some of the more significant differences observed in distribution and geographical range of the ecosystem services that they provide.

At Sudhanyakhali Island, literature searches using the term 'ecosystem services' identified single provisioning, cultural and supporting services, and no regulating services. This contrasted with the multiple services identified across all categories using the RAWES approach. Sudhanyakhali Island had the highest ESI for all 32 ecosystem services relevant to this study and, although deviation from the mean analysis of ESIs revealed generally low provisioning service production other than biochemical and genetic resources, production of supporting, cultural and regulating services was significantly higher relative to all sites. The erosion regulation function was particularly positive, enabled by the active geomorphology and free colonization by mangroves stabilising mudflats. Sudhanyakhali Island also

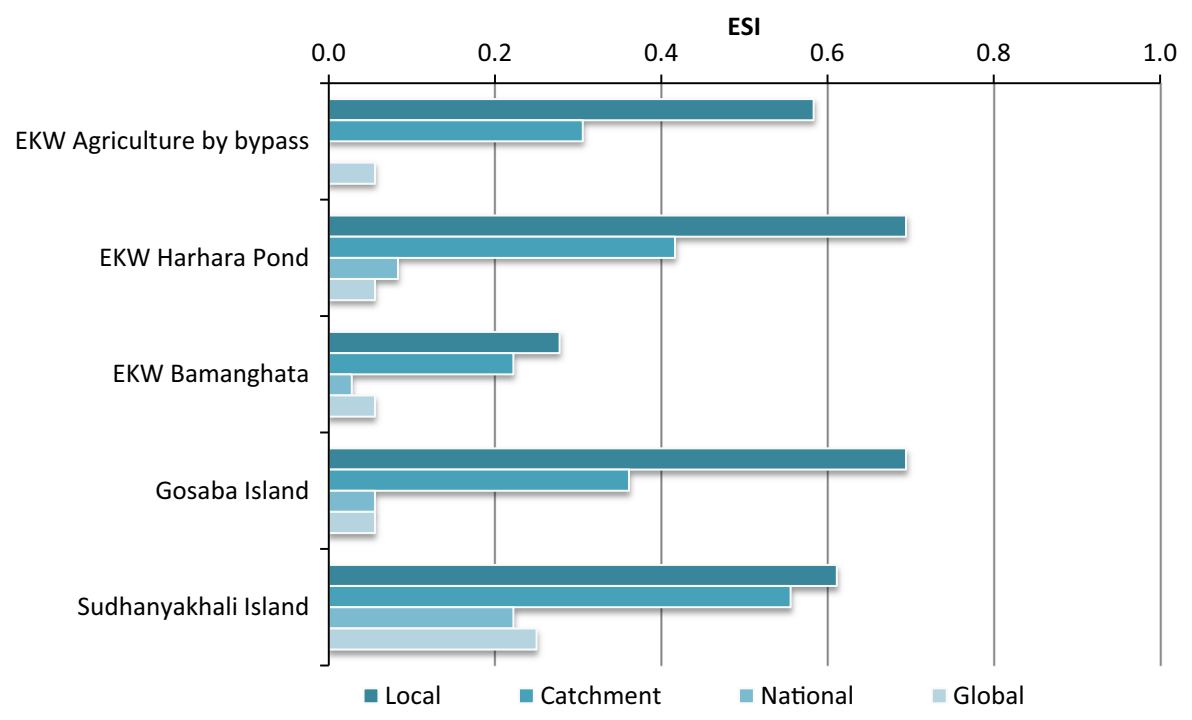

Fig. 5 ESI scores for geographical scales at which wetland benefits accrue 
produced greater national and global benefits than other assessed wetland sites, outcomes consistent with the exclusion of people (other than in controlled resorts) to protect natural character and characteristic wildlife with associated ecosystem processes.

At Gosaba Island, literature searches using the term 'ecosystem services' identified low provisioning $(\mathrm{N}=1)$, cultural $(\mathrm{N}=3)$ and supporting $(\mathrm{N}=1)$ services, and no regulating services. This contrasted with the 28 (including 1 disbenefit) services identified across all categories using the RAWES approach, though with a statistically significant different distribution of services compared to Sudhanyakhali and EKW sites including one negative service (human diseases) and a substantial salinity regulation service compared with other sites. Although Gosaba Island is physically close to Sudhanyakhali Island, separated by the Datta River in places by less than $100 \mathrm{~m}$, RAWES assessment reveals a considerable difference in service production, with low supporting, cultural and regulating services but enhanced provisioning services of local benefit reflecting the extensive food production activities on Gosaba. Delivery of benefits at local scale was equally highest with EKW Harhara Pond, with relatively low adjacent catchment/city, national and global benefits.

At the EKW wetlands, literature searches using the term 'ecosystem services' yielded minimal returns linked to actual ecosystem services. Structured searches using a variety of service-related terms located effectively 2 provisioning (food production in various forms and irrigation), 6 regulating (water purification/treatment/remediation, carbon cycling/ sequestration/climate, water regulation, pest regulation, subsurface hydrology, mosquito regulation), 1 cultural (livelihoods/development) and 3 supporting (nutrient/nutrients/phosphorus cycling, habitat/birds, soil quality) services. Contrasting with these lower numbers, RAWES assessment identified a wider diversity of services across all categories produced by the EKW. These are co-produced despite management of the EKW overwhelmingly for two linked ecosystem services: water purification (a regulating ecosystem service) and the provisioning services of food and flower production (provisioning services), with flood buffering (the 'water regulation' service) also significantly benefitting the city.

At EKW Harhara Pond, the ESI for cultural services was second-highest (after Sudhanyakhali), reflecting the role of the pond ecosystem as a centerpiece of societal organisation, co-producing services across other categories. Local benefits were equally highest (with Gosaba Island) with very low national and global benefits, reflecting the diversion of resources to local food production.

At EKW Bamanghata, ESIs for combined ecosystem service categories were the lowest across the five sites (equal lowest provisioning services with Sudhanyakhali Island), with benefits at local scale substantially higher than at other scales also reflecting management focused on a narrow subset of provisioning services (fish production) for local use.

At EKW Agricultural area, ESIs for combined ecosystem service categories were more closely clustered than at other sites (ranging from 0.29 for regulating services to 0.50 for supporting services) reflecting more balanced service production. The overwhelming distribution of benefits at local and adjacent catchment/city scale relative to modest national and global scales reflect site management to supply local provisioning needs.

The finding that cultural and supporting services have higher ESI scores than provisioning and regulating services across all five sites, Sudhanyakhali Island having highest overall service production, was surprising. For cultural services, this is explained at the four populated and intensively used wetlands (three EKW sites and Gosaba Island) by the ecosystem and its exploitation forming an organising principle for cultural practices and identity, whereas at Sudhanyakhali Island significant cultural benefits result from controlled ecotourism and vicarious values that have driven its Protected status. Supporting services/processes continue to be generated by these ecosystems in spite of varying management pressures. By contrast, provisioning uses tend to focus on a narrower set of services (principally food production) with influence on regulating services that also include a disservice (human disease regulation).

The highest overall service provision at Sudhanyakhali Island does not automatically imply that exclusion of human presence and uses is an effective conservation strategy, as people are important actors shaping the biodiversity and ecosystem services of 'cultural landscapes' (Antrop 2004; Schaich et al. 2010) and therefore integral to wise use of wetlands. In this instance, elevated overall ESIs are explained by the combined weight of supporting, cultural and 
regulating services relative to lower provisioning service ESIs (equally the lowest at both Bamanghata and Sudhanyakhali Island due to differing uses of provisioning services).

Accepting that this study is limited both by number of sites, albeit of diverse character, as well as a limited subset of many possible analyses of RAWES data, statistically significant differences nonetheless emerged in the production of categories of ecosystem services between the five sites. Differences are explained by different use and management at each site. Further analyses of differences between individual ecosystem services within each category would add more insight, but is best conducted on a more extensive survey of wetland sites to reduce statistical error.

Comparison of literature search results with fieldbased RAWES assessments highlights that, if decisions are based solely on currently published knowledge, few ecosystem services would be considered with significant gaps in recognition of services and whole service categories and no systemic overview of service production. These shortfalls in currently published evidence can lead to management responses that are only partially informed, omitting services that may be of vital importance and failing to recognize the inherent systemic interdependencies between all services. This is particularly the case for services where beneficiaries may not be proximal, undermining more remote impacts as, for example, in the cases of wider upstream ramifications of degraded storm buffering services or habitat loss affecting fishery recruitment. Currently, the majority of services produced by the diverse wetlands of West Bengal are not recognised on a systemic basis, and so may be omitted from sustainable development strategies.

Whilst there is often criticism of non-quantitative survey techniques, the overview enabled by RAWES takes consensual account by surveyor teams of the whole interconnected spectrum of ecosystem services, supported by data where available or by integration of local knowledge or other recorded evidence. RAWES also explicitly records nested geographic scales of benefit realisation that might otherwise be overlooked in local-scale assessment. RAWES assessments also highlight how wetland use and management changes the balance of benefits and potential disbenefits flowing from wetlands, as for example in the differing ESI scores between the protected Sudhanyakhali and the adjacent but populated Gosaba islands or the three regions of the EKW under different use and management regimes. These features provide a systemically informed evidence base for decision-making in policy, management and resource use, forming an essential underpinning for sustainable outcomes.

The RAWES approach can also address the concern expressed by Hettiarachchi et al. (2015) that the Ramsar framework under represents peri-urban wetlands; the Ramsar-adopted RAWES approach provides a pragmatic means to redress this balance by identifying the multiple functions and benefits provided by peri-urban wetlands such as the EKW. Recognition of ecosystem services using RAWES also supports a key objective of the Ramsar Convention concerning protection of the ecological character and achievement of wise use of wetlands. RAWES assessments could serve as a practical and rapid approach enabling systemic inclusion of ecosystem services in a wetland inventory for West Bengal and elsewhere, better informing sustainable management.

The authors recognise that the RAWES approach by its nature (and definition) produces a rapid assessment collating qualitatively differing available froms of evidence. This is useful for comprehensive coverage of all linked ecosystem services providing a systemic overview of ecosystem service provision, though further detailed study of specific services may subsequently be necessary to support management and sustainable use decisions within this systemic context. For some purposes, multiple assessment over a time period, which may be by repeated RAWES surveys or ex post using other available published evidence, may be required to detect trends in service flows. Furthermore, a systemic assessment alone may demonstrate a concern but requires further translation if it is to influence policy and practice, as for example although it is known that quality of life for urban citizens can be improved by locally generated services (Bolund and Hunhammar 1999) wetland loss and destruction globally has nonetheless continued apace. 


\section{Conclusions}

- Application of the RAWES approach at five differing wetlands sites in West Bengali integrated different forms of evidence from published sources, direct observations and reports from local people and experts to generate rapid assessments of ecosystem service provision.

- RAWES assessments recognise a broad spectrum of ecosystem services, contrasting with low recognition of ecosystem service production currently in the scientific literature. RAWES assessments are therefore more informative in terms of a systemic basis for management than the narrower findings in the current literature, particularly where the benefits generated by services are remote.

- Across the five assessed sites, ranging from a Protected island to intensively used agricultural systems, the balance of ecosystem services produced across Millennium Ecosystem Assessment categories varies in ways explicable by wetland use and management.

- Service benefits vary in terms of their geographical scale, from the local to the global.

- Although highest overall service provision was observed at the Protected Sudhanyakhali Island, this does not imply that exclusion of human presence and uses is an effective conservation strategy as people are important for wise use of wetlands.

- Many of the ecosystem services provided by surveyed wetlands are underappreciated and undervalued, particularly those provided to Kolkata city by the adjacent East Kolkata Wetland, whilst some management strategies (such as 'hard' coastal defences inhibiting mangrove succession) tend to undermine provision of valuable services.

- Some intensive management and use approaches are nonetheless associated with high supporting service production, with significant associated cultural benefits, constituting a form of wise use of wetlands.

- RAWES assessments on additional sites would add to the insights from this initial study, also reducing statistical errors arising from low sample size.
Acknowledgements This paper was made possible by funding from the India-UK Water Centre (IUKWC: www. iukwc.org), which brought scientists and community members together at events in the Sundarbans and Kolkata, West Bengal, in December 2018. The IUKWC is funded by the Natural Environment Research Council (NERC) in the UK and Ministry of Earth Sciences (MOES) in India. Thanks for support from Dr Sunita Sarkar and Emma Bennett (IUKWC) and Dr Pradip K Sikdar (Indian Institute of Social Welfare and Business Management, Kolkata).

Open Access This article is distributed under the terms of the Creative Commons Attribution 4.0 International License (http://creativecommons.org/licenses/by/4.0/), which permits unrestricted use, distribution, and reproduction in any medium, provided you give appropriate credit to the original author (s) and the source, provide a link to the Creative Commons license, and indicate if changes were made.

Funding The field research was made possible by the IndiaUK Water Centre (IUKWC).

\section{Appendix: Participants in site visits and information-gathering}

Sundarbans Islands

Group visits to the Sundarbans (Gosaba Island and Sudhanyakhali Island) took place from 09th to 11th December 218, with a further day of synthesizing learning in Kolkata on 12th December. Participants offering anonymised input and discussion included:

- Tagore Society for Rural Development (TSRD) community meeting;

- Rangabelia village meeting;

- Various individual farmers;

- Staff of the Gosaba Block Development Office (BDO); and

- Attendee experts at the India-UK Water Centre (IUKWC) Grassroots Field Field Exposure (GFES1) meeting, including:

- 13 covering the disciplines of hydrology, flow modelling and GIS, agricultural meteorology and physics, reservoir management, groundwater modelling and pollution, monsoon prediction, monsoon meteorology, ecosystem functions and geoinformatics for wildlife management, community perceptions and adaptation, Participatory groundwater management, downscaled climate change 
scenarios, groundwater recharge-discharge relationships, and water and soil conservation.

- 6 British scientists spanning the disciplines of climate impacts on water resources, groundwater monitoring and modelling, hydrochemistry, climate variability, ecosystem services, aquatic ecology and bioassessment

\section{East Kolkata Wetland}

Group visits to the East Kolkata Wetland and to workshops in Kolkata with government and other NGO and expert representatives from 12th to 15th December 2018, providing anonymised input and discussion included:

- Mr Anirudh, Environment Department, Government of West Bengal

- Mr Rajual Gain, field supervisor, Environment Department, Government of West Bengal

- Bamangatha:

- Bamangatha Gram Panchayat (comprising 17 members) with attendees including the Prathan (elected headman: Amrash Mondal) and various other Panchayat members

- Chorchoria Fisheries Corporation Limited (CFCS)

- Harhara:

- Rajul Gain, householder; and

- Attendee experts at the India-UK Water Centre (IUKWC) Grassroots Field Field Exposure (GFESs) meeting, including:

- 12 covering the disciplines of hydrology, flow modelling and GIS, monsoon prediction, ecology and waste management, monsoon meteorology, integrated water resource management, groundwater hydrology and environmental impact assessment, impacts and sustainable development of aquatic systems, water contamination and health risk, hazardous and persistent pollutants in surface and ground waters, and water and soil conservation.

- 9 British scientists spanning the disciplines of biogeochemical modelling, flow and transport in porous media, urbanisation and water pollution, sustainable water systems, effects of environmental contaminants on human health, hydrochemistry, climate variability, ecosystem services, aquatic ecology and bioassessment.

\section{References}

Antrop M (2004) Why landscapes of the past are important for the future. Landsc Urban Plan 70(1-2):21-34

Bhattacharya S, Ganguli A, Bose S, Mukhopadhyay A (2012) Biodiversity, traditional practices and sustainability issues of East Kolkata Wetlands: a significance Ramsar site of West Bengal, (India). Res Rev BioSci 6(11):340-347

Bolund P, Hunhammar S (1999) Ecosystem services in urban areas. Ecol Econ 29(2):293-301

Braat LC, de Groot R (2012) The ecosystem services agenda: bridging the worlds of natural science and economics, conservation and development, and public and private policy. Ecosyst Serv 1:4-15

Butchart SHM, Walpole M, Collen B et al (2010) Global biodiversity: indicators of recent declines. Science 328:1164-1168

Centre for Science and Environment (2012) Living with changing climate: impact, vulnerability and adaptation challenges in Indian Sundarbans. Centre for Science and Environment, New Delhi

Choudhury D, Nath D, Chen W (2019) Impact of Indian Ocean warming on increasing trend in pre-monsoon rainfall and Hadley circulation over Bay of Bengal. Theor Appl Climatol. https://doi.org/10.1007/s00704-018-02751-2

Chowdhury AN, Mondal R, Brahma A, Biswas MK (2008) Eco-psychiatry and environmental conservation: study from Sundarban Delta, India. Environ Health Insights. https://doi.org/10.4137/EHI.S935

Datta D (2018) Assessment of mangrove management alternatives in village-fringe forests of Indian Sunderbans: resilient initiatives or short-term nature exploitations? Wetl Ecol Manag 26(3):399-413

Davidson NC, Dinesen L, Fennessey S, Finlayson CM, Grillas P, Grobicki A, McInnes RJ, Murray N, Stroud DA (in press) Wetland ecological status and changes: a metaanalysis. Marine Freshw Res

Deb M, Ferreira CM (2016) Potential impacts of the Sunderban mangrove degradation on future coastal flooding in Bangladesh. J Hydro-environ Res 17:30-46

Ericson JP, Vörösmarty CJ, Dingman SL, Ward LG, Meybeck M (2006) Effective sea-level rise and deltas: causes of change and human dimension implications. Glob Planet Change 50(1-2):63-82

Fennessy MS, Jacobs AD, Kentula ME (2007) An evaluation of rapid methods for assessing the ecological condition of wetlands. Wetlands 27(3):543-560

Ghosh A, Boykoff M (2018) Framing sustainability and climate change: interrogating discourses in vernacular and English-language media in Sundarbans, India. Geoforum. https://doi.org/10.1016/j.geoforum.2018.11.014 
Ghosh S, Das A (2019) Urban expansion induced vulnerability assessment of East Kolkata Wetland using Fuzzy MCDM method. Remote Sens Appl Soc Environ 13:191-203

Ghosh D, Furedy C (1984) Resource-conserving traditions and waste disposal: the garbage farms and sewage-fed fisheries of Calcutta. Conserv Recycl 7(2-4):159-165

Ghosh P, Ghosh A (2018) Is ecotourism a panacea? Political ecology perspectives from the Sundarban Biosphere Reserve, India. GeoJournal 1:11. https://doi.org/10.1007/ s10708-018-9862-7

Ghosh D, Sen S (1987) Ecological history of Calcutta's wetland conversion. Environ Conserv 14(3):219-226

Ghosh A, Schmidt S, Fickert T, Nüsser M (2015) The Indian Sundarban Mangrove forests: history, utilization, conservation strategies and local perception. Diversity 7:149169

Ghosh AR, Mondal S, Kole D (2018) Environmental impact assessment: a case study on East Kolkata Wetlands. In: Jana B, Mandal R, Jayasankar P (eds) Wastewater management through aquaculture. Springer, Singapore

Goswami R, Chatterjee S, Prasad B (2014) Farm types and their economic characterization in complex agro-ecosystems for informed extension intervention: study from coastal West Bengal, India. Agric Food Econ. http://www. agrifoodecon.com/content/2/1/5. Accessed 24 Jan 2019

Gupta H, Kao SJ, Dai M (2012) The role of mega dams in reducing sediment fluxes: a case study of large Asian rivers. J Hydrol 464-465:447-458

Hazra S, Ghosh T, DasGupta R, Sen G (2002) Sea level and associated changes in the Sundarbans. Sci Cult 68(912):309-321

Hettiarachchi M, Morrison TH, McAlpine C (2015) Forty-three years of Ramsar and urban wetlands. Glob Environ Change 32:57-66

Kotze DC, Ellery WN, Macfarlane DM, Jewitt GPW (2012) A rapid assessment method for coupling anthropogenic stressors and wetland ecological condition. Ecol Ind 13 (1):284-293

Kundu N, Chakraborty A (2017) Dependence on ecosystem goods and services: a case study on East Kolkata Wetlands, West Bengal, India. In: Prusty B, Chandra R, Azeez P (eds) Wetland science. Springer, New Delhi, pp 381-405

Kundu N, Pal M, Saha S (2008) East Kolkata wetlands: a resource recovery system through productive activities. In: Sengupta M, Dalwani $\mathrm{R}$ (eds) Proceedings of Taal2007: the 12th world lake conference. pp 868-881

Mahadevia K, Vikas M (2012) Climate change-impact on the Sundarban: a case study. Int Sci J Environ Sci 2:7-15

McInnes RJ, Everard M (2017) Rapid assessment of wetland ecosystem services (RAWES): an example from Colombo, Sri Lanka. Ecosyst Serv 25:89-105

McInnes RJ, Davidson NC, Rostron CP, Simpson M, Finlayson $\mathrm{CM}$ (in press) Valuable insights or fake news? A citizenscience state of the world's wetlands survey, Wetlands

Mehvar S, Filatova T, Sarker MH, Dastgheib A, Ranasinghe R (2019) Climate change-driven losses in ecosystem services of coastal wetlands: a case study in the West coast of Bangladesh. Ocean Coast Manag 169:273-283

Millennium Ecosystem Assessment (2005) Ecosystems and human well-being: synthesis. Island Press, Washington
Mondal B, Dolui G, Pramanik M, Maity S, Biswas SS, Pal R (2017) Urban expansion and wetland shrinkage estimation using a GIS-based model in the East Kolkata Wetland, India. Ecol Ind 83:62-73

Parihar SM, Sarkar S, Dutta A, Sharma S, Dutta T (2013) Characterizing wetland dynamics: a post-classification change detection analysis of the East Kolkata Wetlands using open source satellite data. Geocarto Int 28(3):273287

Raha A, Das S, Banerjee K, Mitra A (2012) Climate change impacts on Indian Sunderbans: a time series analysis (1924-2008). Biodivers Conserv. https://doi.org/10.1007/ s10531-012-0260-Z

Rahman AF, Dragoni D, El-Masri B (2011) Response of the Sundarbans coastline to sea level rise and decreased sediment flow: a remote sensing assessment. Remote Sens Environ 115:3121-3128

Ramsar Commission Secretariat (2002) Ramsar information sheet: East Calcutta Wetlands. Ramsar Commission Secretariat, Gland. https://rsis.ramsar.org/ris/1208. Accessed 24 Jan 2019

Ramsar Convention (2018) Resolution XIII.17: rapidly assessing wetland ecosystem services. 13th meeting of the conference of the contracting parties to the Ramsar convention on wetlands. https://www.ramsar.org/about/cop13resolutions. Accessed 24 Jan 2019

Ray R, Majumder N, Das S, Chowdhury C, Jana TK (2014) Biogeochemical cycle of nitrogen in a tropical mangrove ecosystem, east coast of India. Mar Chem 167:33-43

Roy S (2011) Seasonally and spatially coordinated strategy of detritus conservation and use in the world's largest mangrove ecosystem. Proc Zool Soc 64(2):63-71

Roy C, Guha I (2017) Economics of climate change in the Indian Sundarbans. Glob Bus Rev 1:11. https://doi.org/10. 1177/0972150916668683

RRC-EA (in press) Rapid assessment of ecosystem services: a practitioner's guide. Ramsar Regional Centre-East Asia, Suncheon. Web link when uploaded

Sahu P, Sikdar PK (2008) Hydrochemical framework of the aquifer in and around East Kolkata Wetlands, West Bengal, India. Environ Geol 55(4):823-835

Sanchez-Triana E, Ortolano L, Paul T (2018) Managing waterrelated risks in the West Bengal Sundarbans: policy alternatives and institutions. Int J Water Resour Dev 34 (1):78-96

Schaich H, Bieling C, Plieninger T (2010) Linking ecosystem services with cultural landscape research. GAIA 19 (4):269-277

Singh A, Bhattacharya P, Vyas P, Roy S (2010) Contribution of NTFPs in the livelihood of mangrove forest dwellers of Sundarban. J Hum Ecol 29(3):191-200

Stein ED, Brinson M, Rains MC, Kleindl W, Hauer FR (2009) Wetland assessment debate: wetland assessment alphabet soup: how to choose (or not choose) the right assessment method. Soc Wetl Sci Bull 26(4):20-24

Syvitski JPM, Kettner AJ, Overeem I, Hutton EWH, Hannon MT, Brakenridge GR, Day J, Vörösmarty C, Saito Y, Giosan L, Nicholls RJ (2009) Sinking deltas due to human activities. Nat Geosci 1:11. https://doi.org/10.1038/ ngeo629 
Szabo S, Brondizio E, Renaud FG, HetrickS Nicholls RJ, Matthews Z, Tessler Z, Tejedor A, Sebesvari Z, FoufoulaGeorgiou E, da Costa S, Dearing JA (2016) Population dynamics, delta vulnerability and environmental change: comparison of the Mekong, Ganges-Brahmaputra and Amazon delta regions. Sustain Sci 11(4):539-554

TEEB (2010) The economics of ecosystem and biodiversity (TEEB): ecological and economic foundations. Earthscan, London

Times of India (2009) 23 dead, 1 lakh affected as Cyclone Aila hits Bengal. Times of India, 25th May 2009. https://time sofindia.indiatimes.com/india/23-dead-1-lakh-affected-asCyclone-Aila-hits-Bengal/articleshow/4575274.cms. Accessed 12 May 2019

Trivedi S, Zaman S, Chaudhuri TR, Pramanick P, Fazli P, Amin G, Mitra A (2016) Inter-annual variation in salinity in Indian Sundarbans. Indian J Geo-Marine Sci 45 (3):410-415

Uddin S (2011) Beyond national borders and religious boundaries: Muslim and Hindu veneration of Bonbibi. Engaging South Asian religions: boundaries, appropriations, and resistances. State University of New York Press, Albany, pp 61-81

World Bank (2014) Bangladesh country assistance strategy FY 2011-2014. Word Bank Office, Dhaka

Publisher's Note Springer Nature remains neutral with regard to jurisdictional claims in published maps and institutional affiliations. 